ISSN: 2528-4002 (media online)

ISSN: 2355-892X (print)

Online: http://e-journal.sari-mutiara.ac.id/index.php/KesehatanMasyarakat

DOI: https://doi.org/10.51544/jkmlh.v6i1.1990

\title{
EFEKTIFITAS PEMIJATAN PADA BAYI TERHADAP PENINGKATAN BERAT BADAN BAYI USIA 3- 5 BULAN DI WILAYAH KERJA PUSKESMAS TAPIAN DOLOK KABUPATEN SIMALUNGUN
}

\author{
Parmiana Bangun $^{1 *}$, Renny Sinaga ${ }^{2}$ \\ ${ }^{1}$ Prodi DIII Kebidanan Pematangsiantar Poltekkes Kemenkes Medan, ${ }^{2}$ Prodi DIII Kebidanan \\ Pematangsiantar Poltekkes Kemenkes Medan \\ Email : ${ }^{1}$ parmianabangun83@gmail.com, ${ }^{2}$ rennysinaga.75@gmail.com
}

Received: Januari 2021; Accepted: April 2021; Published: Juni 2021

\begin{abstract}
ABSTRAK
Masa tumbuh kembang bayi merupakan masa keemasan sekaligus masa kritis perkembanganseseorang yaitu pada usia 0-12 bulan. Dikatakan masa keemasan karena masabayi berlangsung sangat singkat dan tidak dapat diulang kembali. Salah satu bentuk stimulasi yang selama ini dilakukan masyarakat adalah dengan pijat bayi,Pijat bayi merupakan rangsangan taktil yang dapat merangsang otot, tulang dan sistem organ agar dapat berfungsi secara optimal. Metode Penelitian ini menggunakan rancangan Quasi experimental dengan pendekatan pretest-posttest control group design. Pretest dilakukan pada kelompok intervensi dan kelompok control mengenai penambahan berat badan bayi sebelum dilakukan pemijatan. Posttest akan dilakukan pada kedua kelompok setelah intervensi diberikan. Hasil : Hasil uji normalitas data dengan uji Shapiro-Wilk pada kelompok eksperimen dari setiap pengukuran maupun peningkatannya menunjukkan tidak berdistribusi normal ( $p<0,05)$; sedangkan pada kelompok kontrol yang datanya berdistribusi normal adalah pada pengukuruan Minggu ke 2, Minggu ke 3, dan pengukuran Minggu ke 4, sedangkan yang lainnya tidak berdistribusi normal. Untuk perbandingan berat badan bayi dari setiap pengukuran karena pada kelompok perlakuan tidak berdistribusi normal, maka uji statistik yang digunakan adalah uji non parametrik dengan uji MannWhitney.simpulan Peningkatan berat badan bayi usia 3 sampai 5 bulan pada kelompok intervensi yang mendapat pemijatan lebih besar daripada kelompok kontrol yang tidak mendapatkan pemijatan
\end{abstract}

Kata Kunci : Pijat bayi, Peningkatan Berat Badan Bayi.

\begin{abstract}
Development of a person is at the age of 0-12 months. It is said to be the golden age because infancy is very short and cannot be repeated. One form of stimulation that has been carried out by the community is baby massage. Baby massage is a tactile stimulation that canstimulate muscles, bones and organ systems to function optimally. Methods This research uses a quasi-experimental design with a pretest-posttest control group design approach. The pretest was conducted in the intervention group and the control group regarding the baby's weight gain before massage. Posttest will be conducted in both groups after the intervention is given. Results: The results of the normality test of the data with the Shapiro-Wilk test in the experimental group from each measurement and the increase showed that they were not normally distributed ( $p<0.05)$; while the control group whose data were normally distributed were on the 2nd Week, 3rd Week, and 4th Week measurements, while the others were not normally distributed. For comparison of the baby's weight from each measurement because the treatment group was not normally distributed, the statistical test used was a non-parametric test with the Mann-Whitney
\end{abstract}


Jurnal Kesehatan Masyarakat dan Lingkungan Hidup

ISSN: 2528-4002 (media online)

ISSN: 2355-892X (print)

Online: http://e-journal.sari-mutiara.ac.id/index.php/KesehatanMasyarakat

DOI: https://doi.org/10.51544/jkmlh.v6i1.1990

test. Conclusions The weight gain of infants aged 3 to 5 months in the intervention group who received massage was greater than in the control group who did not receive massage.

Keywords: Baby massage, Infant Weight Gain.

\section{PENDAHULUAN}

Masa tumbuh kembang bayi merupakan masa keemasan sekaligus masa kritis perkembangan seseorang yaitu pada usia 0-12 bulan. Dikatakan masa keemasan karena masa bayi berlangsung sangat singkat dan tidak dapat diulang kembali. Dikatakan masa kritis karena pada masa ini bayi sangat peka terhadap lingkungan dan membutuhkan asupan gizi serta stimulasi yang baik untuk pertumbuhan dan perkembanganya (Syaukani A, 2015).

Untuk mencapai proses tumbuh kembang yang optimal dipengaruhi oleh beberapa faktor, diantaranya faktor internal dan faktor eksternal. Faktor Internal antara lain usia, jenis kelamin dan keturunan. Dan faktor eksternal misalnya lingkungan, status sosial ekonomi, dan nutrisi. Lingkungan merupakan faktor yang penting karena dengan lingkungan yang baik, bisa mendukung pertumbuhan dan perkembangan anak. Lingkungan yang nyaman, bisa diterapkan oleh orang tua yang mempunyai anak balita, dengan cara melakukan pijat bayi (Pelc $\mathrm{K}, 2017$ ).

Salah satu bentuk stimulasi yang selama ini dilakukan masyarakat adalah dengan pijat bayi,Pijat bayi merupakan rangsangan taktil yang dapat merangsang otot, tulang dan sistem organ agar dapat berfungsi secara optimalSalah satu bentuk stimulasi yang selama ini dilakukan masyarakat adalah dengan pijat bayi,Pijat bayi merupakan rangsangan taktil yang dapat merangsang otot, tulang dan sistem organ agar dapat berfungsi secara optimal. Menurut Health dan Bainbridge, pijat bayi akan merangsang saraf vagus. Saraf ini akan meningkatkan kapasitas kerja peristaltik usus DOI sehingga pengosongan lambung akan lebih cepat dan bayi akan mudah merasa lapar. Selain itu, pijat bayi juga dapat meningkatkan sirkulasi darah dan meningkatkan metabolisme tubuh, sehingga dapat meningkatkan berat badan bayi.

Manfaat pijat bayi antara lain meningkatkan berat dan pertumbuhan tubuh, meningkatkan daya tahan tubuh, meningkatkan konsentrasi bayi dan membuat bayi tidur nyenyak, memupuk ikatan kasih sayang orang tua dan anak,meningkatkan produksi ASI. Pijat bayi juga dapat berdampak negatif jika dilakukan secara tidak tepat seperti trauma atau memar pada kulit dan otot, nyeri pada bayi sehingga bayi menjadi rewel, cedera otot dan tulang, serta bengkak. Selama pijat bayi dilakukan dengan benar dan lembut, pijat bayi aman, bahkan bermanfaat (Summers A, 2018).

Meskipun mekanisme yang mendasari efek terapi pijat pada penambahan berat badan belum diketahui, beberapa kemungkinan telah diusulkan. Satu kemungkinan adalah bahwa pijat meningkatkan aktivitas vagal, yang pada gilirannya melepaskan hormon penyerapan makanan seperti gastrin dan sulin, sehingga dapat berat badan bayi bertambah. Kemungkinan lain adalah bahwa stimulasi ekstensif, misalnya, pijat seluruh tubuh dapat memfasilitasi tindakan pada kulit, dan jaringan lunak serta otot meningkatkan sirkulasi darah dan cairan getah bening. Insulin memegang peranan penting pada metabolisme, menyebabkan kenaikan metabolisme karbohidrat, penyimpanan glikogen, sintesa asam lemak, asam amino, sintesa protein. Jadi, insulin merupakan suatu hormonanabolic penting peningkatan insulin dan gastrin dapat merangsang fungsi pencernaan sehingga penyerapan terhadap 
Jurnal Kesehatan Masyarakat dan Lingkungan Hidup

ISSN: 2528-4002 (media online)

ISSN: 2355-892X (print)

Online: http://e-journal.sari-mutiara.ac.id/index.php/KesehatanMasyarakat

DOI: https://doi.org/10.51544/jkmlh.v6i1.1990

sari makanan menjadi lebih baik, penyerapan makanan yang lebih baik akan menyebabkan bayi cepat lapar(Ma B, 2016).

Kania Richmond A (2015) menyelidiki efek fisiologis dari terapi pijat pada 58 bayi di lembaga. Untuk kelompok eksperimen, diterapkan 2 sampai 3 kali dalam seminggu selama 4 minggu oleh peneliti dan tenaga kesehatan yang terlatih, hasil penelitian ini menyatakan bahwa Bayi yang masuk ke kelompok eksperimen memperoleh penambhan berat badan, tinggi badan, lingkar kepala dan pola tidur yang lama dari pada bayi di kelompok kontrol dengan bayi tanpa pijat(Kania-Richmond A, 2015).

Kanti V (2017) menjelaskan bahwa pijat bayi memberikan kesempatan untuk hubungan ibu dan bayi yang lebih dekat, memungkinkan ibu untuk mengenal bayinya secara lebih rinci, dan meningkatkan daya tanggapnya terhadap bayinya. Para ibu melaporkan pijat bayi membantu masalahmasalah khusus yang dialami bayi mereka, misalnya kolik dan kurang tidur. Ibu juga merasa mereka berkomunikasi lebih baik dengan bayi mereka dan memahami kebutuhan bayi mereka jauh lebih baik, menunjukkan manfaat positif untuk penggunaan pijat bayi(Kanti V,2017).

Sentuhan meningkatkan perasaan dan suasana hati positif umum seseorang dan meningkatkan gairah perhatian, yang kemudian mempengaruhi evaluasi seseorang terhadap rangsangan eksternal di sekitar situasi sentuhan. Oleh karena itu, sentuhan ibu yang tepat termasuk terapi pijat akan menghasilkan perasaan positif secara keseluruhan terhadap ibu dan lingkungan (Visscher MO,2015).

Pijat bayi atau sering disebut stimulus touch dapat merupakan sentuhan komunikasi yang nyaman antara ibu dan bayi. Pijat merupakan terapi sentuhan yang sudah lama dikenal orang, namun masih jarang diterapkan oleh orang tua yang mempunyai anak balita.
Pijat bayi merupakan pengungkapan rasa kasih sayang antara orang tua dengan anak lewat sentuhan pada kulit yang berdampak sangat luar biasa. Sentuhan merupakan ekspresi dari

kasih sayang orang tua terhadap anaknya. Dengan sentuhan tersebut, orang tua dan anak akan sama sama merasa nyaman, karena hubungan kedekatan secara emosional (Virgia.

V, 2015).

Pada saat ini, stimulasi tumbuh kembang pada bayi melalui terapi pijat bayi sangat jarang dilakukan oleh para orangtua karena terbatasnya pengetahuan dan fasilitas dari tenaga kesehatan untuk memberikan informasi dan edukasi tentang terapi ini. Oleh karena itu, peneliti tertarik untuk melakukan penelitian tentang efektifitas pemijatan pada bayi terhadap peningkatan berat badan bayi usia 3- 5 bulan di wilayah kerja puskesmas tapian dolok kabupaten simalungun tahun 2020.

\section{METODE}

Penelitian ini menggunakan rancangan Quasi experimental dengan pendekatan pretest-posttest control group design. Pretest dilakukan pada kelompok intervensi dan kelompok control mengenai penambahan berat badan bayi sebelum dilakukan pemijatan. Posttest akan dilakukan pada kedua kelompok setelah intervensi diberikan. Hasil sebelum dan sesudah intervensi akan dibandingkan antara kelompok intervensi dan kelompok kontrol.

Lokasi penelitian Puskesmas Tapian Dolok Kabupaten Simalungun. Penelitian dilaksanakan pada bulan Juni sampai Juli 2020. Sampel diambil dengan consecutive

\section{DOI}


Jurnal Kesehatan Masyarakat dan Lingkungan Hidup

Vol. 6 No.1 2021

ISSN: 2528-4002 (media online)

ISSN: 2355-892X (print)

Online: http://e-journal.sari-mutiara.ac.id/index.php/KesehatanMasyarakat

DOI: $\underline{\text { https://doi.org/10.51544/jkmlh.v6i1.1990 }}$

Sampling terhadap 60 Bayi. Data yang diperoleh dianalisa dengan uji Shapiro- 2:

Wilk dan uji Chi-square.

\section{HASIL}

Tabel 1. Karak teristik subjek penelitian berdasarkan usia, pendidikan, pekerjaan pada kelompok Intervensi dan Kelompok Kontrol.

\begin{tabular}{|c|c|c|c|}
\hline \multirow[b]{2}{*}{ Karakteristik } & \multicolumn{2}{|c|}{ Kelompok } & \multirow[b]{2}{*}{$\begin{array}{c}\text { Nilai } \\
\mathbf{p}^{*}\end{array}$} \\
\hline & $\begin{array}{c}\text { Intervens } \\
\text { i } \\
(\mathbf{n}=\mathbf{3 0})\end{array}$ & $\begin{array}{l}\text { Kontrol } \\
(\mathbf{n}=30)\end{array}$ & \\
\hline \multicolumn{4}{|l|}{ 1. Jenis kelamin: } \\
\hline Laki-laki & 19 & 18 & \\
\hline Perempuan & 11 & 12 & 0,791 \\
\hline \multicolumn{4}{|l|}{ 2. Usia (bulan) : } \\
\hline 3 & 10 & 10 & \\
\hline 4 & 10 & 10 & 1,0 \\
\hline 5 & 10 & 10 & \\
\hline
\end{tabular}

Berdasarkan tabel 1. Karakteristik subjek penelitian berdasarkan jenis kelamin dan usia bayi sesuai dengan tujuan penelitian, subjek penelitian dikelompokan ke dalam dua kelompok sampel. Kelompok pertama adalah kelompok eksperimen (30 bayi) dan kelompok kedua adalah kelompok kontrol (30 bayi).

Keterangan : *) Nilai p dihitung berdaarkan uji Chi-square.

Tabel 2. Pengaruh Pemijatan terhadap Peningkatan Berat Badan Bayi.Deskriptif Statistik Berat Badan dari setiap Pengukuran.

\begin{tabular}{|c|c|c|c|c|c|}
\hline \multirow[t]{2}{*}{ Berat Badan (gram } & \multicolumn{4}{|c|}{ Ukuran statistik } & \multirow{2}{*}{$\begin{array}{c}\text { Uji } \\
\text { Normalitas } \\
\text { data (nilai } \\
\text { p)* }\end{array}$} \\
\hline & $\begin{array}{l}\text { Rata- } \\
\text { rata }\end{array}$ & SD & Median & Renatng & \\
\hline Data awal : & & & & & \\
\hline Eksperimen & 7486,7 & 627,8 & 7800 & $\begin{array}{c}6100- \\
8300\end{array}$ & 0,003 \\
\hline Kontrol & 7183,3 & 735,3 & 7150 & $\begin{array}{c}6000- \\
8300\end{array}$ & 0,039 \\
\hline $\begin{array}{l}\text { Pengukuran Minggu ke } \\
1:\end{array}$ & & & & & \\
\hline Eksperimen & 7646,7 & 644,6 & 7900 & $\begin{array}{c}6150- \\
8450\end{array}$ & 0,003 \\
\hline Kontrol & 7300 & 736,7 & 7300 & $6150-$ & 0,028 \\
\hline
\end{tabular}

\begin{tabular}{|c|c|c|c|c|c|}
\hline \multirow{2}{*}{$\begin{array}{l}\text { Pengukuran Minggu ke } \\
2:\end{array}$} & \multirow[b]{3}{*}{7805} & \multirow[b]{3}{*}{674,3} & & 8400 & \multirow[b]{3}{*}{0,003} \\
\hline & & & & & \\
\hline Eksperimen & & & & $\begin{array}{c}6300- \\
8600\end{array}$ & \\
\hline Kontrol & 7415 & 732,3 & 7450 & $\begin{array}{c}6250- \\
8550\end{array}$ & 0,063 \\
\hline $\begin{array}{l}\text { Pengukuran Minggu } \\
\text { ke } 3 \text { : }\end{array}$ & & & & & \\
\hline E Eksperimen & 7956,7 & 687,9 & 8250 & $\begin{array}{c}6400- \\
8800\end{array}$ & 0,004 \\
\hline Kontrol & 7515 & 733 & 7550 & $\begin{array}{c}6400- \\
8650 \\
\end{array}$ & 0,055 \\
\hline $\begin{array}{l}\text { Pengukuran Minggu } \\
\text { ke } 4 \text { : }\end{array}$ & & & & & \\
\hline Eksperimen & 8140 & 683,6 & 8400 & $\begin{array}{c}6650- \\
9000\end{array}$ & 0,008 \\
\hline Kontrol & 7598,3 & 769,4 & 7675 & $\begin{array}{c}6000- \\
8700\end{array}$ & 0,15 \\
\hline $\begin{array}{l}\text { Kenaikan awal - } \\
\text { post } 1 \text { : }\end{array}$ & & & & & \\
\hline Eksperimen & 160 & 57,8 & 150 & $50-300$ & 0,018 \\
\hline Kontrol & 116,7 & 40,1 & 100 & $50-250$ & 0 \\
\hline $\begin{array}{l}\text { Kenaikan awal - } \\
\text { post } 2 \text { : }\end{array}$ & & & & & \\
\hline Eksperimen & 318,3 & 212,3 & 375 & -1200 & 0 \\
\hline Kontrol & 231,7 & 60,9 & 225 & $100-350$ & 0,03 \\
\hline $\begin{array}{l}\text { Kenaikan awal - } \\
\text { post } 3 \text { : }\end{array}$ & & & & & \\
\hline Eksperimen & 470 & 229,9 & 500 & -1300 & 0 \\
\hline Kontrol & 331,7 & 76 & 300 & $200-500$ & 0,032 \\
\hline $\begin{array}{l}\text { Kenaikan awal - } \\
\text { post } 4 \text { : }\end{array}$ & & & & & \\
\hline Eksperimen & 653,3 & 244,6 & 700 & -1400 & 0 \\
\hline Kontrol & 415 & 143,9 & 400 & -900 & 0 \\
\hline
\end{tabular}

Keterangan : *) berdasarkan uji Shapiro-Wilk.

Berdasarkan dari hasil pengujian pada tabel 2 menyajikan deskriptif statistik dari berat badan bayi untuk kedua kelompok perlakuan pada berbagai waktu pengukuran. Hasil uji normalitas data dengan uji Shapiro-Wilk pada kelompok eksperimen dari setiap pengukuran maupun peningkatannya menunjukkan tidak berdistribusi normal $(\mathrm{p}<0,05)$; sedangkan pada kelompok kontrol yang datanya berdistribusi normal adalah pada pengukuruan Minggu ke 2, Minggu ke 3, dan pengukuran Minggu ke 4, sedangkan yang lainnya tidak berdistribusi normal. Untuk perbandingan berat badan bayi dari setiap pengukuran karena pada kelompok perlakuan tidak berdistribusi normal, maka uji statistik yang digunakan adalah uji non parametrik dengan uji Mann-Whitney

DOI 
Jurnal Kesehatan Masyarakat dan Lingkungan Hidup

ISSN: 2528-4002 (media online)

ISSN: 2355-892X (print)

Online: http://e-journal.sari-mutiara.ac.id/index.php/KesehatanMasyarakat

DOI: https://doi.org/10.51544/jkmlh.v6i1.1990

Tabel 3. Perbandingan Berat Badan dari Berbagai Waktu Pengukuran pada kedua Kedua Kelompok Penelitian.

\begin{tabular}{|c|c|c|c|}
\hline \multirow[b]{2}{*}{$\begin{array}{l}\text { Berat } \\
\text { badan } \\
\text { (gram) }\end{array}$} & \multicolumn{2}{|c|}{ Kelompok } & \multirow[b]{2}{*}{$\underset{\mathbf{p}^{*)}}{\text { Nilai }}$} \\
\hline & $\begin{array}{l}\text { Eksperimen } \\
\quad(\mathbf{n}=\mathbf{3 0})\end{array}$ & $\begin{array}{l}\text { Kontrol } \\
(n=30)\end{array}$ & \\
\hline Data awal: & $\begin{array}{c}7800^{* *} \\
(6100-8300)\end{array}$ & $\begin{array}{c}7150 \\
(6000- \\
8300)\end{array}$ & 0,185 \\
\hline $\begin{array}{l}\text { Pengukuran } \\
\text { Minggu ke } 1 \\
\text { : }\end{array}$ & $\begin{array}{c}7900 \\
(6150-8450)\end{array}$ & $\begin{array}{c}7300 \\
(6150- \\
8400)\end{array}$ & 0,124 \\
\hline $\begin{array}{l}\text { Pengukuran } \\
\text { Minggu ke } 2 \\
\text { : }\end{array}$ & $\begin{array}{c}8125 \\
(6300-8600)\end{array}$ & $\begin{array}{c}7450 \\
(6250- \\
8550)\end{array}$ & 0,059 \\
\hline $\begin{array}{l}\text { Pengukuran } \\
\text { Minggu ke } 3 \\
\text { : }\end{array}$ & $\begin{array}{c}8250 \\
(6400-8800)\end{array}$ & $\begin{array}{c}7550 \\
(6400- \\
8650)\end{array}$ & 0,024 \\
\hline $\begin{array}{l}\text { Pengukuran } \\
\text { Minggu ke } 4 \\
\text { : }\end{array}$ & $\begin{array}{c}8400 \\
(6650-9000)\end{array}$ & $\begin{array}{c}7675 \\
(6000- \\
8700)\end{array}$ & 0,008 \\
\hline \multicolumn{4}{|l|}{$\begin{array}{l}\text { Kenaikan } \\
\text { (nilai } \\
\text { median) : }\end{array}$} \\
\hline $\begin{array}{l}\text { Data awal - } \\
\text { post } 1\end{array}$ & 150 & 100 & 0,002 \\
\hline $\begin{array}{l}\text { Data awal - } \\
\text { post } 2\end{array}$ & 375 & 225 & $<0,001$ \\
\hline $\begin{array}{l}\text { Data awal - } \\
\text { post } 3\end{array}$ & 500 & 300 & $<0,001$ \\
\hline $\begin{array}{l}\text { Data awal - } \\
\text { post } 4\end{array}$ & 700 & 400 & $<0,001$ \\
\hline
\end{tabular}

Keterangan : *) nilai p dihitung berdasarkan uji Mann-Whitney.**) nilai median dan rentang.

Berdasarkan hasil perhitungan pada tabel 3 tampak pada data awal berat badan bayi tidak menunjukkan ada perbedaan yang bermakna ( $\mathrm{p}>0,05)$. Pada pengukuran minggu ke-1, dan minggu ke- 2 juga tampak berat bayi pada kedua kelompok perlakuan tidak bermakna, sedangkan pada pengukuran minggu ke - 3 dan minggu ke - 4 menunjukkan ada perbedaan yang bermakna $(\mathrm{p}<0,05)$; pada kelompok eksperimen nilai mediannya lebih tinggi bila dibandingkan dengan kelompok kontrol.

Selanjutnya, berdasarkan kenaikan berat badan terhadap berat badan awal, kenaikan pada pengukuran minggu ke 1, 2, 3 dan ke 4 menunjukkan ada perbedaan yang sangat bermakna $(\mathrm{p}<0,01)$. Pada pengukuran ke 4, pada kelompok eksperimen terjadi peningkatan berat badan 700 gram, sedangkan pada kelompok kontrol hanya 400 gram.

Tabel 4 Rata-rata berat badan bayi yang terjadi pada kedua kelompok pengamatannya, digambarkan kedalam bentuk grafis.

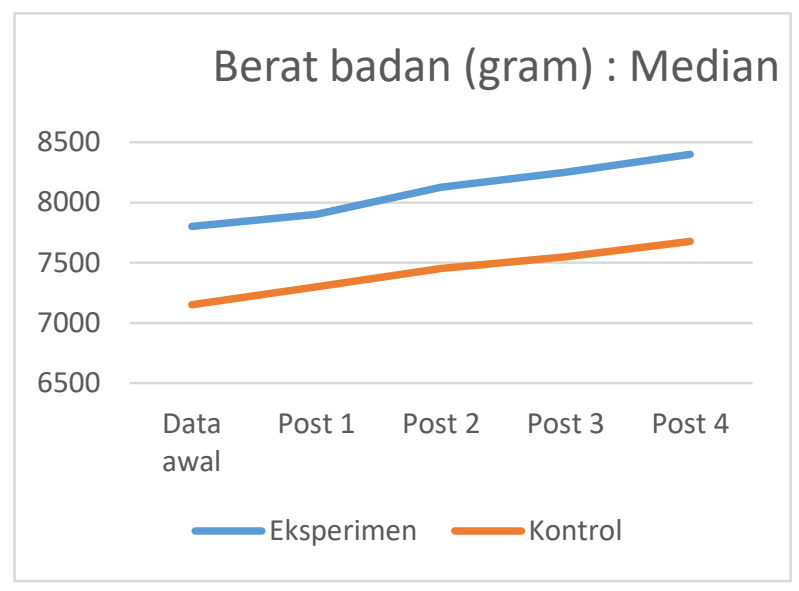

Gambar 4.1 Perbandingan rata-rata Berat badan dari berbagai waktu pengukuran pada kedua kelompok penelitian selama 4 minggu.

\section{PEMBAHASAN}

Berdasarkan hasil analisis pada table 1 dapat disimpulkan bahwa peningkatan berat badan pada kelompok eksperimen lebih besar daripada kelompok Kontrol ( $p<0,001)$. Hal ini membuktikan bahwa pemijatan memengaruhi peningkatan berat badan bayi.

Secara teori dapat dijelaskan bahwa persyarafan pada saluran cerna sepenuhnya otonom. Suplai saraf parasimpatis dihantarkan dari abdomen melalui saraf vagus. Saraf vagus adalah saraf kepala 
Jurnal Kesehatan Masyarakat dan Lingkungan Hidup

ISSN: 2528-4002 (media online)

Vol. 6 No.1 2021

ISSN: 2355-892X (print)

Online: http://e-journal.sari-mutiara.ac.id/index.php/KesehatanMasyarakat

DOI: https://doi.org/10.51544/jkmlh.v6i1.1990

kesepuluh yang mengantarkan fungsi organ tubuh termaksud dibagian dada dan perut. Rangsangan saraf vagus akan merangsang lambung untuk mengeluarkan hormong astrin. Hormon gastrin akan merangsang pengeluaran insulin, asam khidroklorida, pepsinogen, enzim pankreas, mucus, peningkatan aliran empedu hati dan merangsang motilitas lambung (relaksasi semestara) sehingga lambung dapat menambah volumenya dengan sangat mudah tanpa peningkatan tekanan. Saat makanan sampai pada duodenum maka akan merangsang pengeluaran cholecystokini hal ini akan merangsang motilitas usus, sehingga akan mempermudah pencampran, pendorongan makanan dan penyerapan nutrisi menjadi lebih baik (Summers A, 2018).

Hasil penelitian yang dilakukan oleh Bennett , membuktikan bahwa pemijatan yang dilakukan pada bayi premature selama 10 hari dan bayi dipijat 2 kali/hari membuktikan terdapat peningkatan tonus saraf vagus yang signifikan setelah pemijatan daripada sebelum pemijatan pada kelompok intervensi, sedangkan pada kelompok control tidak ada perubahan. Beberapa penelelitian juga menyatakan bahwa aktifitas vagus berhubungan dengan peningkatan pertumbuhan bayi. Aktivitas vagus pada akhirnya akan merangsang motilitas gastric dan usus sehingga membantu absorbs makanan ke usus. Peningkatan motilitas gasctric akan membuat bayi sering lapar, hal ini merupakan media untuk peningkatan berat badan bayi(Bennett C, 2013).

Penelitian yang dilakukan oleh Kim kepada 58 bayi cukup bulan yaitu kelompok intervensi 30 bayi dan kelompok kontrol 28 bayi. Penijatan dilakukan selama 3 bulan setelah kelahiran. Kelompok intervensi menerima pemijatan 2 kali sehari selama 4 minggu. Hasil penelitian menunjukan bahwa terdapat peningkatan berat badan, panjang badan, lingkar kepala pada kelompok

\section{DOI}

intervensi yang lebih besar daripada kelompok control dan menyampaikan bahwa pemijatan sangat efektif untuk mengoptimalkan pertumbuhan bayi.

Kesimpulan dari beberapa peneliti di bahwa pemijatan dapat meningkatkan berat badan bayi premature dan cukup bulan pada kelompok intervensi yang lebih besar daripada kelompok kontrol. Pertumbuhan dan fungsi organ pada bayi premature belum sempurna daripada bayi cukup bulan, sehingga diperlukan stimulasi (pemijatan) yang lebih sering daripada bayi cukup bulan sampai berat badannya menjadi optimal.

\section{SIMPULAN DAN SARAN SIMPULAN}

Berdasarkan hasil penelitian dan pembahasan maka dapat disimpulkan sebagai berikut :Peningkatan berat badan bayi usia 3 sampai 5 bulan pada kelompok intervensi yang mendapat pemijatan lebih besar daripada kelompok kontrol yang tidak mendapatkan pemijatan.

\section{SARAN}

1. Untuk meningkatkan keterampilan bidan maka dibutuhkan pelatihan pijat bayi. Diharapkan dengan keterampilan ini bidan dapat melaksanakan pijat bayi secara rutin sebagai asuhan yang diberikan pada bayi dan dapat lebih meningkatkan monitoring terhadap berat badan bayi secara rutin dipuskesmas.

2. Perlunya meningkatkan kompetensi / keterampilan pijat bayi pada beberapa bidan diwilayah kota pematangsiantar melalui pelatihan.

3. Penelitian selanjutnya diharapkan mengobservasi secara langsung frekuensi menyusu dan lama tidur bayi.

\section{DAFTAR PUSTKA}


Online: http://e-journal.sari-mutiara.ac.id/index.php/KesehatanMasyarakat

DOI: https://doi.org/10.51544/jkmlh.v6i1.1990

Bennett C, Underdown A, BarlowJ. (2013). Massage for promoting mental andphysical healthintypically developing infantsunder the ageof six months(Review) :Cochrane Database of Systematic Reviews;Issue 4.Art. No.: CD005038.

Dahlan MS. (2011). Statistik untuk Kedokteran dan Kesehatan. Jakarta: Salemba Medika.

Dahlan MS. (2010). Besar Sampel dan Cara Pengambilan Sampel. Jakarta: Salemba Medika.

Kania-Richmond A, Reece BF, Suter E, Verhoef MJ. The professional role of massage therapists in patient care in Canadian urban hospitals - a mixed methods study. BMC Complem Altern M. 2015;15:20

Kanti V, Günther M, Stroux A, Sawatzky S, Henrich W, Abou-Dakn M, Blume Peytavi U, Garcia Bartels N. Influence of sunflower seed oil or baby lotion on the skin barrier function of newborns: A pilot study. J Cosmet Dermatol. 2017;16(4):500 -507. https://doi.org/10.1111/jocd.12302

Ma B. Clinical analysis of anterograde and retrograde massage therapy for treatment of children rotaviral enteritis. Modern Health. 2016;18:86.

MenkesRI.PMKNo.8Tahun 2014. Pelayanan Kesehatan SPA

Pelc K, Daniel I, Wenderickx B, Dan B, Primebrain g. Multicentre 357 prospective randomised single-blind controlled study protocol 358 of the effect of an additional parent-administered sensorimotor 359 stimulation on neurological development of preterm infants: 360 primebrain. BMJ Open. 2017;7:e018084
Syaukani A. Petunjuk Praktis Pijat, Senam, dan Yoga Sehat untuk Bayi. Yogyakarta: Araska. 2015.

Summers A, Visscher MO, Khatry SK, Sherchand JB, LeClerq SC, Katz J, Tielsch JM, Mullany LC. Indicators of skin barrier integrity among newborns massaged with mustard oil in rural Nepal. J Perinatol. 2018;38(1):64-70.

Visscher MO, Adam R, Brink S, Odio M. Newborn infant skin: physiology, development, and care. Clin Dermatol. 2015;33(3):271-80.

Virgia. V. 2015. Pengaruh Pijat Bayi terhadap Perkembangan Neonatus. Jurnal Keperawatan \& Kebidanan, STIKES Dian Husada Mojokerto, Vol 8 dan No 1 : 7279.https://jurnalonline.lppmdianhusada.ac.i d/index.php/jkk/article/view/44/23 